\title{
Phonetic norm versus usage in advanced French as a second language
}

\author{
ALAIN THOMAS
}

Abstract

This article is drawn from a large-scale ongoing study on linguistic progress in advanced French as a second language (FL2). The performance of 48 Englishspeaking students who spent their third year of university in France (the 'experimental' group) has been compared to that of 39 classmates who chose to stay and study at home in southern Ontario, Canada (the 'control' group).

The analysis presented here will be limited to three morpho-phonemic variables where native speaker usage can differ considerably from official norms, i.e., 'liaison', schwa and the negative particle ne. Results generally point to different pronunciation difficulties at the advanced level than at the beginners' level. Also, comparisons between the experimental and the control groups lead to a reappraisal of the notions of 'norm' and phonetic 'progress' in spoken French.

\section{Introduction}

While everyone agrees that students returning from a year abroad are more fluent in the language of study, little is known about the exact nature of this improvement. Indeed, in her overview of research in this area, Barbara Freed (1995: 16) notes that "no study has yet described a range of linguistic variables (phonologic, syntactic and/or semantic), sociolinguistic and discourse features, that may be influenced as a result of a study abroad experience".

In an attempt to partially fill this gap for the French language, we have undertaken a large-scale quantitative and qualitative study of the progress made in second language proficiency over one academic year by university students specializing in French. Two subgroups have been identified: an experimental group of students spending their third year in France, and a control group of those staying in Ontario instead. The survey is also intended to paint an overall picture of the strengths and weaknesses of our students in French, for pedagog- 
ical and corrective purposes. The two main questions addressed in this research are as follows:

1. What are the actual linguistic benefits of studying abroad: improved accent, accuracy, idiomatic speech, fluency, syntactic complexity, oral expression, listening comprehension? Better discourse strategies, broader sociolinguistic variety?

2. How does student proficiency differ between those who have lived abroad and those whose instruction was limited to the formal second language classroom?

The research reported on in this paper is limited to the morphophonetic aspect of the students' production and it focuses on several interesting features of French pronunciation where usage can vary widely from the official norm: 'liaison', schwa and the negative particle $n e$ 'not'. In contrast to simple phonemes such as /y/ or /Ø/, which tend to be very stable throughout the French-speaking community (they are normally not deleted and essentially realized the same way everywhere), the features examined here are extremely variable, going from full realization to full deletion, depending on such factors as phonetic context, degree of formality and rate of speech. They also display striking differences between official norm and usage. For our students therefore, the question is not simply to imitate a native speaker model, as they would in a language laboratory, but also to deal with several of them and to understand their sociolinguistic constraints. The analysis of these features will thus take us beyond student performance and into sociolinguistic competence and the whole question of norm versus usage, as experienced by foreign learners of the French language.

\section{Methodology}

Seven south-Ontario universities with exchange programs in France were selected for this study: Guelph, Toronto, Trent, Waterloo, Western Ontario, Wilfrid Laurier and Windsor. Thanks to the generous collaboration of the teachers and administrators of these programs, close to 100 third-year students were tested in quasi-identical conditions, since the 52-minute test, which was entirely prerecorded - even the pauses - could be administered by anyone with the proper recording facilities. The test was administered twice, at the beginning and at the end of the academic year, for comparison purposes. After eliminating faulty recordings for technical reasons or incompleteness, we were left with 87 subjects, mostly females, all in their third year of study, who had taken at least 4 semester courses in French during the period considered.

To answer the second research question (see Section 1), participants were divided according to the nature and the intensity of their linguistic experience. The 39 students who stayed in Ontario (the 'control' group) took between 4 
and 6 French courses in an English-speaking environment, while the 48 students who went to France (the 'experimental' group) generally took 10 French courses, and in a French-speaking environment. Naturally, the latter group was expected to improve more in French than their stay-at-home counterparts. The question under study, therefore, is essentially to document this development qualitatively and quantitatively.

Two subtests were used for the phonetic analysis of the corpus. First and foremost, a 12-minute semidirected test of oral expression, based on three consecutive exercises, which yielded over 190,000 words of spontaneous speech:

- A description of a particularly interesting cover of the New Yorker magazine, full of anomalous people and activities;

- A description of the student's university for advertising purposes;

- A past tense narration of the student's autobiography.

The phonetic analysis is also based on a reading of two stylistically 'neutral' texts - one on wine and the other on Astérix characters - totaling 441 words. Read twice by 87 subjects, these texts yielded a supplementary corpus of 76,000 words, which will be used here for the study of the lexical dimension of schwa variation.

The maintenance/deletion of each variable under study was duly recorded on orthographical transcriptions of the students' productions. The data thus obtained was used to calculate percentages of maintenance for each style, each subject, each group, and for the totality of the participants. The z-test of statistical significance was applied to intergroup differences, with $\mathrm{z}>1.64$ (at $\mathrm{p}<$ 0.05 ) as main criterion of reliability (for details, see Butler 1985: 79-84). Finally, it should be noted that, to facilitate comparisons, all percentages quoted here refer to the maintenance of a variant - never to its absence or deletion and that applies as well to the results of previous studies, which were adapted accordingly.

\section{3. 'Liaison'}

\subsection{Background}

Liaison is a complex feature of coarticulation, typical of French pronunciation. It originates in the progressive weakening of final consonants since Old French, a process which has never been completed before vowels and which is largely governed by lexico-syntactic and socio-stylistic considerations. Hence a set of tendencies which have so far eluded rigorous categorization. Factors conducive to its realization are numerous and complementary. They mostly amount to a tight relationship between the words involved (internal position in a phrase, satellite status before a noun or a verb, higher rate of speech), which materializes through a phonetic connection in $/ \mathrm{z} /, \mathrm{lt} / \mathrm{or} / \mathrm{n} /$, in most cases. 


\section{Alain Thomas}

Liaison is sometimes the only way to make important distinctions in noun or verb phrases (leur idée 'their idea' leurs idées 'their ideas'; il avance 'he goes forward' $\sim$ ils avancent 'they go forward'), or even in rare cases of ambiguity, such as ton front est ceint 'your head is girdled' in the Canadian national anthem, where liaison evokes a much less noble image than the one intended. It clearly has, therefore, phonological value. Since it is also very frequent (more than $/ y /$, for instance, in our corpus), it is important that it be pronounced properly.

\subsection{Compulsory liaisons}

In order to quantify our observations, we first considered faulty the deletion of 'compulsory' liaisons, as defined by Ågren (1973) and Malécot (1975), or their realization with the wrong consonant. A total of 7,395 possible occurrences of this type of liaison were found in the corpus, which confirms its frequency and therefore its importance. Table 1 shows the results of our analysis, as compared to Malécot's work in Paris, within each grammatical context where liaison is supposed to occur.

Overall, $91.1 \%$ of all possible compulsory liaisons were realized by our students, as opposed to $96.9 \%$ by Malécot's Parisians. At first glance, this seems impressive enough, but if one looks at the liaisons, which were not - or erroneously - realized ( $8.9 \%$ vs. $3.1 \%$ ), it becomes obvious that our students make nearly three times as many errors as Francophones in this area. Furthermore, a comparison of compulsory liaison with other pronunciations difficulties analyzed in Thomas (1988a, same corpus) reveals that liaison accounts for nearly $20 \%$ of all the phonetic errors made by students. Such figures should clearly be cause for concern and remedial efforts on the pedagogical front.

The breakdown of our students' results into grammatical categories is similar to that of the Paris middle class (Malécot 1975) for the most common words: determiners, pronouns and prepositions. But important differences appear when adjectives (especially grand 'great') and the conjunction quand 'when' are examined. It would seem that the weakest results are obtained with words in $-d$, which becomes /t/ in liaison. This suggests that students may know more or less where and when to place liaison, but have difficulty choosing the right liaison consonant, when it deviates from the dominant model of close correspondence between writing and speech (as in elles /z/ ont /t/ été acceptées en $\mathrm{ln} /$ automne, le premier $/ \mathrm{r}$ / octobre 'they were accepted in the fall on October 1st)

Interestingly, $8.5 \%$ of correct liaisons were realized without proper enchaînement, or forward linking ( $28.7 \%$ for un_. homme 'a man'). But, contrary to the speech of several presidents of France studied by Encrevé (1988), for whom this realization is a form of oratory affectation, it is mostly for our students 
Table 1. Maintenance of compulsory liaison in FL1 and FL2

\begin{tabular}{|c|c|c|c|c|c|c|}
\hline \multirow[t]{2}{*}{ Category } & \multicolumn{3}{|c|}{ Malécot (FL1) } & \multicolumn{3}{|c|}{ Thomas (FL2) } \\
\hline & $\mathrm{N}$ & $\%$ & & $\mathrm{~N}$ & $\%$ & \\
\hline \multirow[t]{4}{*}{ Determiners } & 621 & 99.5 & (art.) & 2351 & 96.4 & \\
\hline & 354 & 93.2 & (adj.) & & & \\
\hline & & & & 95 & 52.6 & (un_oiseau) \\
\hline & & & & 580 & 99.1 & $\begin{array}{l}(\text { un_homme) } \\
\text { [of which 28.7_.] }\end{array}$ \\
\hline \multirow{4}{*}{$\begin{array}{l}\text { Monosyllabic } \\
\text { prepositions }\end{array}$} & 182 & 98.8 & & 663 & 95.6 & \\
\hline & 81 & 98.8 & (dans_) & 410 & 96.3 & (dans_) \\
\hline & 76 & 100 & $\left(e n \_\right)$ & 334 & 97 & $\left(e n \_\right)$ \\
\hline & 6 & 85.7 & (sans_) & 11 & 81.8 & (sans_) \\
\hline \multirow[t]{3}{*}{ Personal pronouns } & $860^{\mathrm{a}}$ & 98.2 & & 821 & 96.3 & \\
\hline & & & & 512 & 97.7 & (on_) \\
\hline & & & & 77 & 77.9 & (ils/elles_) \\
\hline \multirow{3}{*}{$\begin{array}{l}\text { Monosyllabic adverbs } \\
\text { except pas, puis }\end{array}$} & $92^{\mathrm{a}}$ & $91.3^{\mathrm{a}}$ & & 387 & 85.3 & \\
\hline & 41 & 92.7 & (très_) & 184 & 84.8 & \\
\hline & & & & 65 & 92.3 & (tout_) \\
\hline \multirow[t]{4}{*}{ Adjectives } & 354 & 93.2 & & 348 & 49.7 & (qualifying) \\
\hline & & & & 154 & 54.5 & $($ petit-s_) \\
\hline & & & & 28 & 25 & (grand-s_) \\
\hline & & & & 311 & 91 & (numeral) \\
\hline Conjunctions & & & & 64 & 40.6 & (quand_) \\
\hline Total & 2667 & 96.9 & & 7395 & 91.1 & \\
\hline
\end{tabular}

a Figures based on Malécot's work, although not mentioned by the author himself

a mark of hesitation associated with difficult words (ses_. ennemis 'his enemies') or simply the influence of their mother tongue, English, where closed syllables predominate. Another anomaly worth noting is the particularly low rate of liaison in un_oiseau 'a bird' (52.6\%), which contrasts sharply with the $96.4 \%$ average in the Det $+\mathrm{N}$ category. Because of their mother tongue, many subjects likely perceive $o i$ as starting with the $/ \mathrm{w} /$ glide, which already exists in French in such borrowings as les/waters 'the washroom', un/western 'a western movie'. The irregularity of the rule governing the use of liaison before /w/ in FL1 naturally creates confusion among learners in FL2.

\subsection{Optional liaisons}

The analysis of optional liaison confirms the main tendencies observed with the compulsory type. Wherever a comparison with previous research is pos- 
Table 2. Maintenance of optional and forbidden liaisons in FL1 and FL2

\begin{tabular}{lrrrrr}
\hline Category & \multicolumn{2}{c}{ Ågren (FL1) } & & \multicolumn{2}{c}{ Thomas (FL2) } \\
\cline { 2 - 3 } \cline { 5 - 6 } & $\mathrm{N}$ & $\%$ & & $\mathrm{~N}$ & $\%$ \\
\hline Optional & & & & \\
est & 2569 & 97 & & 1297 & 66.2 \\
sont & 279 & 86 & & 164 & 51.2 \\
suis & 139 & 47 & & 211 & 5.8 \\
était & 364 & 75 & & 104 & 29.6 \\
ont & 381 & 75 & 27 & \\
Forbidden & & & 9 & \\
\hline
\end{tabular}

sible - using Ågren's (1973) work on radio recordings, which is much more detailed than Malécot's - our students appear once more to make fewer liaisons than Francophones. To some extent, they may be following a dominant trend toward the general weakening of liaison everywhere, as documented by Smith (1998), for instance. But it is more likely that, faced with the daunting task of acquiring the complex set of linguistic and sociolinguistic constraints of optional liaisons, they simply choose the easier and more natural solution for them, i.e., the absence of liaison. Their use of occasional 'forbidden' liaisons further demonstrates their difficulty with this complex feature of French pronunciation.

\subsection{Discussion}

Section 3.2 clearly shows that the realization of compulsory liaison leads to numerous errors, especially outside the 'determiner' category, despite the advanced status of our students. By contrast, the phonetic difficulties considered typical of Anglophone learners ( $/ \mathrm{y} /, / \mathrm{\Psi} /, / \mathrm{R} /$, and nasals) have already been mastered by a vast majority of them (see Thomas 1988a). This is not surprising, if one considers the near absence of lessons on liaison in FL2 textbooks, at all levels of the Ontario educational system. Yet, as I have tried to show elsewhere (Thomas 1988b), this problem is not pedagogically insurmountable.

In addition, the high number of liaisons without linking suggests that certain errors should be reanalyzed within the wider framework of consonantal linking, which some students replace with word boundaries based on written French or on English syllabification (for instance avec une amie 'with a friend' pronounced /a-vek-yn-a-mi/ instead of /a-ve-ky-na-mi/). Any attempt at corrective phonetics here should first address the general question of open syllabification in French, before applying it to the special case of liaison, which has its own variations and constraints. 


\section{Schwa}

\subsection{Background}

Defined here as any orthographic $e$ which is deleted or pronounced /ə/, schwa finds it origin in unstressed Latin vowels, notably /a/, which progressively centralized and weakened, to the point of complete disappearance in certain contexts (see Latin /rósa/ > Old French /roza/ > Modern French /Roz/), very much like liaison. Schwa goes back at least to the 9th century, since it is found in the Strasburg Oaths, written in 842. Its deletion, already common internally in the14th century (sairement > serment 'oath'), appeared later in final postvocalic position, but with compensatory lengthening of the previous vowel (aimé aimée 'loved'), as found today among certain speakers in Belgium, French Ardennes or Normandy. Since the 19th century, deletion has increasingly spread to all positions in northern French, to the point of occurring in words devoid of an orthographic $e$ in the first place (Monsieur > M'sieur 'Sir'; faisait $>$ f'sait 'did'). According to available data on contemporary French, reproduced in Table 3, deletion prevails over maintenance and it is particularly popular among the young (Hansen 1994: 34). But how far can it go? Researchers disagree on this point, arguing for (Walter 1990: 29) or against (Hansen 1994: 33) its stabilization in word-initial position. The least that can be said is that the complete disappearance of schwa is impossible, because it would result in unpronounceable consonantal clusters ( ${ }^{*}$ mercr' $d i$ 'Wednesday'). The question is therefore far from settled.

\subsection{Contextual variation}

A mini-corpus of potential schwa occurrences was drawn from the transcriptions of the recordings. Given the importance of phonetic context and the futility of quantifying near-categorical phenomena (for instance final / $/$ /, always deleted, or /a/ following two consonants, generally maintained), only cases of potentially wide variation were retained, i.e., /ə/ following single consonants.

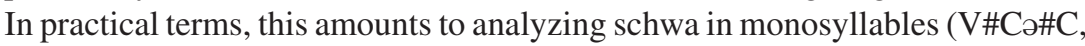
dans l[e] fond 'at the far end') and in internal position ( $\mathrm{VC} 2 \mathrm{C}$, lent[e]ment 'slowly'). Successive monosyllables were counted like regular ones because the choice remains binary: maintenance of both /ə/ (on me le dit 'They say it to me') or deletion of one (on m' le dit or on me l' dit), but not deletion of both (* on m' l' dit). Finally, all special cases where there was in fact no choice (dans le euh ... camion 'in the uh ... truck') were eliminated. This process yielded 5,419 possible occurrences of /ə/ in $\mathrm{V \# Cə \# C} \mathrm{and} \mathrm{1,301} \mathrm{in} \mathrm{VCəC,} \mathrm{i.e.,} \mathrm{between}$ 12 and 16 schwas per subject, which proved to be sufficient to show variation patterns. 
Table 3. Schwa maintenance in FL1 and FL2

\begin{tabular}{|c|c|c|c|c|c|c|c|c|c|c|c|c|}
\hline & \multicolumn{12}{|c|}{ Studies } \\
\hline & \multicolumn{2}{|c|}{ L1 Paris ${ }^{\mathrm{a}}$} & \multicolumn{2}{|c|}{ L1 Paris ${ }^{b}$} & \multicolumn{2}{|c|}{ L1 Orléans ${ }^{\mathrm{c}}$} & \multicolumn{2}{|c|}{ L1 Ontario $^{\mathrm{d}}$} & \multicolumn{2}{|c|}{ L2 immers ${ }^{\mathrm{e}}$} & \multicolumn{2}{|c|}{ L2 univers ${ }^{\mathrm{f}}$} \\
\hline & $\mathrm{N}$ & $\%$ & $\mathrm{~N}$ & $\%$ & $\mathrm{~N}$ & $\%$ & $\mathrm{~N}$ & $\%$ & $\mathrm{~N}$ & $\%$ & $\mathrm{~N}$ & $\%$ \\
\hline \multicolumn{13}{|l|}{ Context } \\
\hline V\#Cә\#C & & 29 & & 32 & 3768 & 53 & 4947 & 31.4 & 958 & 92.3 & 5419 & 77.9 \\
\hline VCəC & 379 & 3 & & 0.8 & 4912 & 21.9 & 1296 & 5.4 & 195 & 24.8 & 1301 & 17 \\
\hline All contexts & 10891 & 53 & 8657 & & 11589 & 34.5 & 17039 & 41.7 & 2707 & 79.3 & & \\
\hline
\end{tabular}

a Malécot (1977)

b Hansen (1994)

c Delbecq and Debrocque (1986)

d Mougeon, Nadasdi, Rehner, and Uritescu (2002)

e Uritescu, Mougeon, Rehner, and Nadasdi (this issue)

$\mathrm{f}$ Thomas (this issue)

The background research summed up in Table 3 calls for several remarks:

1. In all cases, /a/ is much better maintained in monosyllables, where it contributes heavily to word identity, than in internal position, where its contribution is negligible.

2. Overall, FL2 speakers maintain more schwas than their FL1 counterparts. Just as in the case of optional liaison, students are not comfortable enough with their second language to go very far in the deletion of underlying segments.

3. However, that difference is almost nonexistent in internal position. This suggests that FL2 speakers have no difficulty following the French model when words have essentially a single pronunciation, with or without /ə/ (mercredi 'Wednesday' $\sim$ sam'di 'Saturday'), but they are more hesitant with contextdependent words, like monosyllables.

\subsection{Lexical variation}

Because the presence of certain words in spontaneous speech is too random to lend itself to analysis, it was necessary to look at the reading corpus to study the lexical dimension of schwa variation. Thus each word under consideration appeared at least 174 times (read by 87 subjects in their pre- and post-tests), which presents an obvious advantage for the statistical reliability of the results.

Table 4 shows that /ə/ variation does not stop with the contextual categories discussed above, as was already noted by Hansen (1994) and Walker (1996) for FL1. First, all monosyllables do not behave the same way, as demonstrated by the relative vulnerability of /ə/ in the expression ce qui, as opposed to its constant presence in other monosyllables. Second, in internal position, it is 
Table 4. Lexical variation in schwa maintenance (reading)

\begin{tabular}{lrc}
\hline Context & $\mathrm{N}$ & $\%$ \\
\hline V\#Cə\#C & & \\
$\quad$ ce qui & 348 & 90.2 \\
Others & 2784 & 99.9 \\
Total & 3132 & 99.9 \\
VCəC & & \\
$\quad$ changement & 174 & 0 \\
bouleversement & 174 & 9.8 \\
vigneron & 174 & 78.2 \\
certainement & 174 & 2.3 \\
jugements & 174 & 0 \\
ennemis & 174 & 58 \\
Total & 1044 & 24.7 \\
\hline
\end{tabular}

the -ment suffix which is the most clearly correlated with /ə/ deletion. Internal juncture seems to encourage deletion, as does external juncture (e.g., atelier 'work shop' $\sim$ donn' lieu 'brings about'). This is particularly evident when one compares certainement 'certainly' and ennemis 'enemies', where /a/ is treated very differently, although appearing in exactly the same phonetic environment. More important factors are clearly at play here, such as the absence of a suffix in ennemis and the attraction of English enemy, where /ə/ is always maintained. At the very least, this brief lexical analysis demonstrates that schwa variation is almost infinite and that the major tendencies noted in previous research constitute only a first step toward the understanding of this very complex problem.

\subsection{Discussion}

The analysis of schwa variation in our corpus confirms that, as in French immersion programs (see Uritescu, Mougeon, Rehner, and Nadasdi, this issue), our advanced students find themselves halfway between the official norm of standard French, high in schwa retention, and colloquial usage, which prefers deletion. Less exposed than Francophones to French in general and to its colloquial varieties in particular, FL2 students are naturally less sensitive to the contextual constraints of the variable. 


\section{Alain Thomas}

\section{Negative $n e$}

\subsection{Background}

French two-part negations find their origin in Latin non 'not', which became so weak over the centuries, going from non to no, ne and finally $n$ ', that it had to be reinforced by a noun usually denoting smallness: pas 'step', point 'point', goutte 'drop', mie 'crumb', etc. First optional, this noun became necessary in the 17th century for all negations, to the point of eventually replacing ne in its negative function and relegating it to the stylistic domain. Contemporary French has largely become devoid of $n e$, as least in familiar speech. Ne deletion is therefore the logical result of the progressive sliding of French negation towards the end of verb phrases. It is reinforced by ne's lack of semantic precision, by its unaccented and redundant character, and by a recent tendency in modern French toward the amalgamation of verbs and their pronominal subjects, which runs counter to ne insertion. According to language historians, this process goes back to the 16th century. Recent observations suggest that it is ongoing and possibly gathering momentum. In two interesting diachronic studies (Ashby 2001; Armstrong and Smith 2002), surveys have been replicated with a twenty-year gap, with results showing in both cases a drop of $20 \%$ in $n e$ retention, which is considerable in such a short time. Clearly ne is declining in France, and may well reach levels already observed in Canada, where its absence is nearly complete. Far from being an error therefore, ne deletion is becoming the norm in spoken French, a fact that should not be ignored in our classrooms, especially with advanced students.

Among FL1 speakers, frequency of $n e$ deletion varies considerably as a function of linguistic, stylistic and social factors (see recent reviews in Gadet 2000 or Armstrong and Smith 2002). For instance, in highly formal speech, retention can be as high as $92.6 \%$ (Ågren 1973) and, in the casual register of younger speakers, it has been found to be as low as 1\% (Pooley 1996). FL2 students who are in contact with Francophones outside the academic or media contexts may therefore hear mostly $n e$-less negations and one can expect their imitation of this new model to be correlated with the duration of their contacts with the vernacular, as suggested by the available research.

Looking at previous research on the use of $n e$ in FL2 (Table 5), one can distinguish three broad categories, clearly based on the type of experience learners have had with the French language:

1. Low maintenance (11\%): a group of Anglophone Montrealers, who have always been in contact with Quebeckers who almost never use $n e$.

2. Middle maintenance (50-58\%): Hispanics, Asians, Irish or Americans, whose contact with moderate $n e$ users from France is intense but short.

3. High maintenance (73-81\%): students in Flanders (core French) or Ontario (French immersion), who rarely meet Francophones outside the classroom. 
Table 5. Previous research on ne maintenance in FL2

\begin{tabular}{lccl}
\hline Reference & $\begin{array}{c}\text { N of } \\
\text { speakers }\end{array}$ & $\begin{array}{c}\text { Maintenance } \\
\text { of } n e^{\mathrm{a}}(\%)\end{array}$ & Setting \\
\hline Thibault and Sankoff 1997 & 17 & 11 & English speakers in Montreal \\
Painchaud, d'Anglejan, and & 36 & 59 & Orientals in Montreal \\
$\begin{array}{l}\text { Vincent 1982 } \\
\text { Trévise and Noyau 1984 }\end{array}$ & 8 & 58 & Spanish speakers in France \\
Regan 1996 & 6 & 50 & $\begin{array}{l}\text { English speakers in France } \\
\text { English speakers in France }\end{array}$ \\
Sax 1999 & 18 & $58^{\mathrm{b}}$ & $\begin{array}{l}\text { English speakers in Toronto } \\
\text { Rehner and Mougeon 1999 }\end{array}$ \\
$\begin{array}{l}\text { (French immersion) } \\
\text { Dewaele and Regan 2002 }\end{array}$ & 17 & 73 & $\begin{array}{l}\text { Flemish speakers in Flanders } \\
\text { (regular FSL classes) }\end{array}$ \\
\hline
\end{tabular}

a Results originally published in terms of deletion are given here in terms of maintenance b Data not specifically given by the authors, but inferred from their results

Table 6. Contextual variation of ne

\begin{tabular}{lrc}
\hline Category & $\mathrm{N}$ & Maintained $(\%)$ \\
\hline ne...pas & 1319 & 72.2 \\
ne..plus/rien/jamais/personne & 46 & 71.7 \\
ne \# V & 814 & 75.9 \\
ne \# C & 551 & 66.6 \\
Total & 1365 & 72.1 \\
\hline
\end{tabular}

In this context, one can expect our advanced students to be essentially in the 'high maintenance' category, because of their reduced contacts with Francophones, but leaning toward the 'middle', thanks to their greater fluency and sensitivity to stylistic variation. This leaning should be particularly prevalent among the experimental group, after one year spent in France.

\subsection{Contextual variation}

A total of 1,365 occurrences of negation (ne ... pas 'not'/jamais 'never'/rien 'nothing'/personne 'no-one') - i.e., an average of 15.7 per subject - were found in the spontaneous speech corpus. The presence/absence of ne was duly recorded in every case, with the consolidated results shown in Table 6.

Since ne was only one of many variables examined in our research, its study was not as detailed as in other works specifically devoted to it (notably Coveney 1996; Dewaele and Regan 2002; and Armstrong and Smith 2002), where var- 
ious grammatical contexts and levels of formality are taken into account. Our analysis is therefore limited to two dimensions: phonetic context and type of adverbial negators used.

One striking feature of the data in Table 6 is the overwhelming presence of pas in the corpus. Accounting for $96.6 \%$ of all occurrences, it relegates the other negations to the level of mere exceptions. This figure is the same as found among French immersion students (Rehner and Mougeon 1999), but much higher than comparable data from France (80-82\%, according to Gadet 1989; Gougenheim et al. 1967; and Ashby 1976). Words which are infrequent in FL1 are even more so in FL2 and our students, who know these other negations passively, may not be confident enough to use them actively.

As for ne maintenance, it is roughly the same here for all negators, which contrasts with the situation in France, where it is lower for pas (see Ashby 1976, 1981; Gadet 1989, and Armstrong and Smith 2002), mostly because of such frequent pre-formed sequences as c'est pas 'it's not', je sais pas 'I don't know', y a pas 'there is not', $i$ ' faut pas 'one must not', etc. It stands to reason that these sequences are uttered less rapidly, and therefore more completely, by learners who are still constructing them than by Francophones who have long treated them as basic formulae.

The data regarding phonetic context are similar to what previous research indicates, both in FL1 (Ashby 1976, 1981) and FL2 (Regan 1996; Sax 1999). $\mathrm{Ne}$ is best maintained in pre- (or inter-) vocalic context, which suggests that our students are somewhat sensitive to the preference for open syllabification in French.

Finally, the overall maintenance average of $72.1 \%$ is much higher than in France, even in conservative circles, but again similar to that of the French immersion students mentioned above. Clearly, despite their advanced status conducive to subtle stylistic differences, our students remain influenced first and foremost by the formal and academic context in which they operate. Ne maintenance may also have been reinforced by the influence of written French, which is greater in university than at lower levels of education. Whatever the reason, our students are obviously 'high maintenance' speakers, along with others who have little contact with Francophones outside the educational context.

\section{French as a second language versus French as a first language}

The comparison of surveys carried out in different contexts and using different methods of investigation is fraught with danger. It is only through generalizations covering several variables, each studied by several researchers using similar methodologies that one can hope to make reliable claims. In Table 7, a summary of our main findings and of related research is presented, to better understand the differences between FL1 and FL2 pronunciation, with respect 
Table 7. FL2 versus FL1 overall performance

\begin{tabular}{lccccl}
\hline Variable & $\mathrm{N}$ & $\begin{array}{c}\mathrm{N} / \\
\text { Speakers }\end{array}$ & $\begin{array}{c}\text { \% Maintained } \\
\text { Thomas (FL2) }\end{array}$ & $\begin{array}{c}\text { \% Maintained } \\
\text { (FL1) }\end{array}$ \\
\hline Compulsory liaison & 7395 & 85 & 91 & 96.9 & (Malécot 1975) \\
est_liaison & 1297 & 15 & 66 & & \\
Schwa (monosyllable) & 5419 & 62 & 77 & 71.7 & (Malécot 1975) \\
ne & 1365 & 16 & 72.1 & 29 & (Malécot 1977) \\
& & & & $32-53$ & (2 others) \\
& & & & $1-92$ & (13 studies) \\
\hline
\end{tabular}

to the variables examined here. The two left columns show that our results are based on a substantial number of occurrences, which never fall below an average of 15 per subject. The right columns indicate to what extent the 'full' variant of each variable has been maintained, both in our corpus and in comparable FL1 studies.

Two opposing tendencies emerge from the analysis. On one hand, our students make fewer liaisons than the control group (here Malécot's 1975 Parisian bourgeoisie). On the other hand, they maintain the full variants much more often than their L1 counterparts in the other two variables. How could one explain this apparent contradiction?

In the first case, the results can be explained by the difficulty of coarticulation, by a more hesitant rate of speech which is not conducive to liaison and, in general, by the fact that our students are still learners of French, and therefore naturally prone to an imperfect imitation of the target language. The small gap between the two columns, which looks the same for all liaisons in absolute terms $(5-6 \%)$, is in fact much more significant for compulsory liaisons in relative terms, because in this case it highlights the difference between near perfection (FL1) and numerous errors (FL2), while for est 'is', liaison is just a little more optional for one group than for the other.

In the second instance, results are baffling at first, since FL2 students seem to do better than the French themselves on expected variants. But to what extent are these variants really 'expected'? If one looks at the relevant research, it quickly becomes obvious that schwa and ne maintenance is more the exception than the rule in France, and even more so in Quebec. Conversely, liaison after est is still strong, and compulsory liaison nearly universal among the French middle class. This reality eludes our students from the control group, whose experience of French is limited to the written code - where deletion is practically unknown - or to the French spoken by their professors, who tend to confine themselves to formal speech, either by choice or out of necessity. Students are therefore caught between two opposite forces: official norms and actual usage. 


\section{Alain Thomas}

When both coincide, as in compulsory liaison, students behave the same as with other difficulties of French: they try and imitate a single universal model, with increasing degrees of success as they become more advanced. When usage deviates considerably from the norm, as with schwa and ne, they don't know which model to choose and end up somewhere between the $100 \%$ possible maximum and real maintenance levels falling below $50 \%$. Hence their results, which hover around $75 \%$ maintenance. Liaison with est may thus be seen as a transition between these two areas of higher and lower FL2 maintenance of the full variants.

Finally, it is worth noting that percentages are much more consistent in FL2 than in FL1. This could be yet another illustration of our students' largely monostylistic French. Rarely in contact with popular or familiar registers, they mainly imitate the dominant neutral or formal styles of the academic world. Also, daunted by the enormous task of teaching stylistic and sociolinguistic variation, teachers often limit themselves to the basics, i.e., efficient communication with as few major errors as possible, leaving style for later. And they may be right, considering that native speakers generally expect little more from L2 speakers, and can be put off by their failed attempts at nonstandard speech (for instance, swearing with a foreign accent).

\section{Home versus abroad dimension}

In an attempt to answer our main research question on home versus abroad study, we have regrouped in a single table the amalgamated pre-test and posttest results obtained for each group and each variable. The difference between the two tests represents the students' progress or regression towards the maximum possible maintenance $(100 \%)$ of the full variants, and the $\mathrm{z}$ test of statistical validity measures its degree of significance.

The differences presented in Table 8 are generally small, especially in the case of compulsory liaison, despite the fact that its compulsory nature is obvious to everyone (although there could also be a 'ceiling effect' here, with percentages so close to $100 \%$ ). Clearly, eight months of studies in French, even in a total immersion environment, cannot drastically change the pronunciation of advanced students, which was already established before their third year of university.

However, small as they may be, these differences are consistent in their direction. The control group always progresses towards the norm, which suggests that whatever French was taught that year in the traditional context of Ontario universities has contributed indirectly to the improvement of the students' pronunciation. Results of the experimental group are less obvious. While they too show progress in compulsory liaison, they seem to regress everywhere else, precisely where native speakers deviate from the norm. It's as if the long pro- 
Table 8. Home versus abroad results

\begin{tabular}{llcccc}
\hline Variable & & $\begin{array}{c}\text { Pre-test } \\
\%\end{array}$ & $\begin{array}{c}\text { Post-test } \\
\%\end{array}$ & $\begin{array}{c}\text { Differ } \\
\%\end{array}$ & $\mathrm{z}$ Test \\
\hline Compulsory liaison & Experimental & 86.7 & 90.8 & +4.1 & $\mathrm{z}=0.5$ \\
& Control & 91.1 & 93.9 & +2.8 & \\
est_liaison & Experimental & 67.9 & 60.3 & -7.6 & $\mathrm{z}=2.99^{\mathrm{a}}$ \\
\multirow{4}{*}{ Schwa } & Control & 65 & 73.8 & +8.8 & \\
& Experimental & 80.4 & 75.4 & -5 & $\mathrm{z}=1.91^{\mathrm{b}}$ \\
& Control & 77.3 & 78.5 & +1.2 & \\
& Experimental & 78.7 & 72.6 & -6.1 & $\mathrm{z}=3.2^{\mathrm{a}}$ \\
& Control & 68 & 80.3 & +12.3 & \\
\hline
\end{tabular}

a highly significant difference

b barely significant difference

cess toward standard pronunciation was suddenly reversed in France, because of intense contacts with a (mostly young) population, which does not practice it. This analysis thus confirms a fundamental distinction between compulsory liaison and the other variables. Only the status of optional liaison remains unclear at this point: from transition between two opposing tendencies in Table 7 to unambiguous regression here. Actually, diachronic and social reasons may account for this detail. Given the social connotations of optional liaison and a diachronic tendency toward weakening (see Thomas 1988b), it may well be that the $71.7 \%$ figure recorded by Malécot in 1975 for middle class Parisians would have been considerably lower had the interviews been conducted one generation later and among the student population which most clearly defined the language experience of our experimental group in France.

\section{Conclusion}

The study of liaison, schwa and ne variation in the speech of advanced FL2 speakers has shown that these speakers' phonetic performance, just like the French immersion Ontario students studied by Rehner and Mougeon, falls somewhere between the rigorous application of maintenance rules inspired by written French, and the laxist productions of Francophones in spontaneous speech. Less exposed to French than native speakers, the FL2 speakers are understandably less sensitive to its contextual and stylistic variation.

However, for study-abroad students, a distinction must be made between phonetic features universally used by the native speakers (here, compulsory liaison) and those largely dependent on stylistic and social factors (est, schwa and ne). In the first case, they come closer to the target variants than their classmates who stayed in Canada during the same period, presumably thanks 
to their intensive contacts with the French-speaking population. In the second case, however, they appear to pull away from the target. But this is only a 'regression' within the context of academic French, which encourages the maintenance of full variants and tends to consider their deletion as typical of popular, therefore 'faulty', speech (see Blanche-Benveniste and Jeanjean 1986: 1, 11 and 21). Yet, as we are reminded by Blanche-Benveniste (1997: 38 , our translation), "certain common pronunciations, although different from academic speech, are so widespread that they cannot be considered marginal." Familiar French must be distinguished from popular French, as suggested by Valdman (1982: 227), to avoid blocking the acquisition of the former by condemning the latter, and its "mildly marked variants" (Rehner, Mougeon, and Nadasdi 2003) must also be included in the FSL curriculum. In this context, the performance of our experimental group may be seen as a form of progress, because students improved in their imitation of this new norm of spoken French, based on the real pronunciation of mainstream ordinary Francophones.

Must we then extend this type of progress to the learners who don't go abroad, which is the vast majority of our students? After all, there is nothing wrong with using optional variants considered officially desirable and an 'academic' performance could suffice in a university context. That would also keep our students closer to the ideal of written performance, which still is a central concern at the university level. However, as pointed out by Pohl (1975: 23), there are cases where speaking French too well amounts to speaking it badly. One should be able to expect from advanced students that they add a stylistic dimension to their linguistic competence, already well established, and that they be aware of the main variable patterns of French, aside from its categorical rules.

Our research confirms findings from previous studies (Dewaele and Regan 2002; Rehner, Mougeon and Nadasdi 2003), namely that the acquisition of sociolinguistic competence is less affected by an increase in class hours than by direct contact with the French-speaking population. Hence the need to expose our students to colloquial French, preferably through extended stays in a francophone area, or through exchange programs which bring French-speaking youths to our classes, in the shape of teaching assistants or second language monitors. And if this sort of direct contact is unavailable, we should at the very least include more diversity in our language models, especially at the advanced level. Such measures are necessary if we want our students to go beyond the type of academic French represented in most teaching methods - where variation is not even acknowledged, let alone taught (cf. Mougeon, Nadasdi, and Rehner 2002) - and thus facilitate their contacts with the real French-speaking world.

University of Guelph <thomas@uoguelph.ca> 


\section{References}

Ågren, John (1973). Étude sur quelques liaisons facultatives dans le français de conversation radiophonique: fréquence et facteurs. Acta Universitatis Uppsaliensis, Studia Romanica Uppsaliensia 10, Uppsala.

Armstrong, Nigel and Alan Smith (2002). The influence of linguistic and social factors on the recent decline of ne. French Language Studies 12: 23-41.

Ashby, William (1976). The loss of the negative morpheme ne in Parisian French. Lingua 39: 119-137.

- (1981). The loss of the negative particle ne in French, a syntactic change in progress. Language 57: 674-687.

- (2001). Un nouveau regard sur la chute du ne en français parlé tourangeau: s'agit-il d'un changement en cours? Journal of French Language Studies 11: 1-22.

Blanche-Benveniste, Claire and Colette Jeanjean (1986). Le français parlé: Transcription et édition. Paris: Didier.

Blanche-Benveniste, Claire (1997). Approches de la langue parlée en français. Paris: Ophrys.

Butler, Christopher (1985). Statistics in Linguistics. Butler: Blackwell.

Coveney, Aidan B. (1996). Variability in Spoken French. A Sociolinguistic Study of Interrogation and Variation. Exeter: Elm Bank.

Delbecque, Nicole and M. Debrock (1986). Le $e$ muet, vérification sur un corpus de français parlé. In Méthodes Quantitatives et Informatiques dans l'Étude des Textes/Computers in Literary and Linguistic Research, Etienne Brunet and Charles Muller (eds.), 255-272. Geneva: Slatkine/Paris: Champion.

Dewaele, Jean-Marc and Vera Regan (2002). Maîtriser la norme sociolinguistique en interlangue française: le cas de l'omission variable de ne. Journal of French Language Studies 12: 123148

Encrevé, Pierre (1988). La liaison avec et sans enchaînement. Phonologie tridimensionnelle et usages du français. Paris: Seuil.

Freed, Barbara (ed.) (1995). Second Language Acquisition in a Study Abroad Context. Amsterdam: John Benjamins.

Gadet, Françoise (1989). Le français ordinaire. Paris: Armand Colin.

- (2000). Des corpus pour (ne) ... pas. In Corpus, Méthodologie et Applications Linguistiques, Mireille Bilger (ed.), 156-167. Paris: Champion.

Gougenheim, Georges, R. Michéa, Paul Rivenc, and Aurélien Sauvageot (1967). L'élaboration du français fondamental ( $1^{e r}$ degré). Paris: Didier.

Hansen, Anita B. (1994). Étude du e caduc: stabilisation en cours et variations lexicales. Journal of French Language Studies 4: 25-54.

Malécot, André (1975). French liaison as a function of grammatical, phonetic and paralinguistic variables. Phonetica 32: 161-179.

- (1977). The effect of linguistic and paralinguistic variables on the elision of the French mute e. Phonetica 33: 93-112.

Mougeon, Raymond, Terry Nadasdi, and Katherine Rehner (2002). État de la recherche sur l'appropriation de la variation par les apprenants avancés du FL2 ou FLE. In L'acquisition de la variation par les apprenants du français langue seconde, Jean-Marc Dewaele and Raymond Mougeon (eds.), Special issue of Acquisition et interaction en langue étrangère 17: 7-50.

Mougeon, Raymond, Terry Nadasdi, Katherine Rehner, and Dorin Uritescu (2002). The sharing of constraints in minority speech communities. Paper presented at the NWAVE 31 conference, Stanford University.

Painchaud, Gisèle, Alison d'Anglejan, and Diane Vincent (1982). Acquisition du français par un groupe d'immigrants asiatiques. Research report, Faculté des Sciences de l'Éducation, Université de Montréal.

Pohl, Jacques (1975). L'omission de ne dans le français parlé contemporain. Le Français dans le monde 111: 77-23. 


\section{Alain Thomas}

Pooley, Tim (1996). Chtimi: The Urban Vernacular of Northern France. Clevedon: Multilingual Matters.

Regan, Vera (1996). Variation in French interlanguage: A longitudinal study of sociolinguistic competence. In Second Language Acquisition and Linguistic Variation, Robert Bayley and Dennis R. Preston (eds.), 177-201. Philadelphia: Benjamins.

Rehner, Katherine and Raymond Mougeon (1999). Variation in the spoken French of immersion students: To ne or not to ne, that is the sociolinguistic question. Canadian Modern Language Review 56: 124-154.

Rehner, Katherine, Raymond Mougeon, and Terry Nadasdi (2003). The learning of sociolinguistic variation by advanced FSL learners: The case of nous versus on in Immersion French. Studies in Second Language Acquisition 25: 127-156.

Sax, Kelly (1999). The acquisition of stylistic variation by American learners of French: The case of negation. Paper presented at the NWAVE 28 conference, Toronto.

Smith, Alan (1998). French variable liaison: A proposed simplification. Francophonie 17: 11-14.

Thibault, Pierrete and Gillian Sankoff (1997). L'insertion d'une langue seconde dans le répertoire d'une communauté linguistique: le français parlé par les Anglo-Montréalais. Paper presented at the NWAVE 26 conference, Quebec City.

Thomas, Alain (1988a). Nos étudiants avancés ont-ils besoin de leçons de phonétique? Paper presented at the Journées de Phonétique, University of Western Ontario, London, Ontario.

- (1988b). La liaison et son enseignement: des modèles orthoépiques à la réalité linguistique. Canadian Modern Language Review 54: 543-552.

Trévise, Anne and Colette Noyau (1984). Adult Spanish speakers and the acquisition of French negation forms: individual variation and linguistic awareness. In Second Language: A CrossLinguistic Perspective, Roger W. Andersen (ed.), 165-189. Rowley: Newbury House.

Valdman, Albert (1982). Français standard et français populaire: sociolectes ou fictions? French Review 56: 219-227.

Walker, Doug C (1996). The new stability of unstable $e$ in French, Journal of French Language Studies 6: 221-229.

Walter, Henriette (1990). Une voyelle qui ne veut pas mourir. In Variation and Change in French, John N. Green and Wendy Ayres-Bennett (eds.), 27-36. London: Routledge. 